Situs Jurnal : http://ejurnal.stiepancasetia.ac.id/index.php/jieb

Jilid 4 Nomor 3 November 2018

Hal $419-433$

\title{
PENYUSUNAN ANGGARAN, KEPUASAN KERJA DAN KOMITMEN ORGANISASI TERHADAP KINERJA ORGANISASI PADA DINAS KEBUDAYAAN, PARIWISATA, KEPEMUDAAN DAN OLAHRAGA KABUPATEN BARITO TIMUR
}

\section{Rabiatul Awalliah*}

Abstract: The aims of this research to determine the effect of budgetary participation, job satisfaction and organizational commitment to organizational performance at the Department of Culture, Tourism, Youth and Sports of East District Barito. Respondents in this study amounted to 40 employees of the Department of Culture, Tourism, Youth and Sports District of East District Barito set by census Technique of collecting data in the form of questionnaires, direct interview and observation.Measurement scale of questionnaire using Likert scale with intervals 1 through 5 .The research instrument wastested by validation test and the data was tested by multiple linear regression analysis with the help SPSS version 24 for windows program. The results showed that budgeting participation, job satisfaction and organizational commitment together influence organizational performance. Partially budgeting participation and organizational commitment have a significant effect on organizational performance while job satisfaction does not affect organizational performance at the Department of Culture, Tourism, Youth and Sports of East District Barito.Budgeting participation is the most dominant variable affecting the performance of the organization.

Keywords: Budgeting participation, job satisfaction, organizational commitment, organizational performance

Abstrak: Penelitian ini bertujuan untuk mengetahui pengaruh partisipasi penyusunan anggaran, kepuasan kerja dan komitmen organisasi terhadap kinerja organisasi pada Dinas Kebudayaan, Pariwisata, Kepemudaan dan Olah raga Kabupaten Barito Timur. Responden dalam penelitian ini berjumlah 40 orang pegawai Dinas Kebudayaan, Pariwisata, Kepemudaan dan Olah raga Kabupaten Barito Timur yang ditetapkan secara sensus. Teknik pengumpulan data berupa kuesioner, wawancara langsung dan observasi. Skala pengukuran kuesioner menggunakan skala likert dengan interval 1 sampai dengan 5. Instrumen penelitian diuji dengan ujivaliditas dan uji reliabilitas dan data diuji dengan analisis regresi linier berganda dengan bantuan program SPSS versi 24 for windows.Hasil penelitian menunjukkan bahwa partisipasi penyusunan anggaran, kepuasan kerja dan komitmen organisasi secara bersama-sama berpengaruh terhadap kinerja organisasi. Secara parsial partisipasi penyusunan anggaran dan komitmen organisasi berpengaruh signifikan terhadap kinerja organisasi sedangkan kepuasan kerja tidak berpengaruh terhadap kinerja organisasi pada Dinas Kebudayaan, Pariwisata, Kepemudaan dan Olahraga Kabupaten Barito Timur. Partisipasi penyusunan anggaran merupakan variabel paling dominan berpengaruh terhadap kinerja organisasi.

Kata kunci : Partisipasi penyusunan anggaran, kepuasan kerja, komitmen organisasi, kinerja organisasi.

* Dinas Kebudayaan, Pariwisata, Kepemudaan dan Olahraga Kabupaten Barito Timur 


\section{Latar Belakang}

Pelaksanaan pemerintahan yang baik dan bersih (Good Governance) di daerah merupakan isu yang paling mengemuka dalam pengelolaan administrasi publik dewasa ini. Pelaksanaan penyelenggaraan pemerintahan yang baik tercermin dalam sistem akuntabilitas kinerja instansi pemerintah. Akuntabilitas merupakan perwujudan kewajiban instansi untuk mempertanggung jawabkan keberhasilan dan kegagalan pelaksanaan misi dalam mencapai tujuan dan sasaran yang telah ditetapkan melalui pertanggungjawaban yang dilaksanakan secara berkala. Berdasarkan Undang-Undang Nomor 25 Tahun 2004 tentang Sistem Perencanaan Pembangunan Nasional (SPPN), diamanatkan bahwa daerah harus menyusun rencana pembangunan daerah secara sistematis, terarah, terpadu, menyeluruh, dan tanggap terhadap perubahan (ayat (2) Pasal 2), dengan jenjang perencanaan yaitu perencanaan jangka panjang, perencanaan jangka menengah, maupun perencanaan tahunan. Untuk itu daerah menyusun dan menetapkan Rencana Pembangunan Jangka Panjang (RPJP) Daerah, Rencana Pembangunan Jangka Menengah (RPJM) Daerah, dan dijabarkan dalam Rencana Kerja Pemerintah Daerah (RKPD).

Dalam suatu organisasi, anggaran memegang peran penting dimana anggaran merupakan suatu rencana keuangan yang disusun secara sistematis dalam menunjang terlaksananya program kegiatan suatu organisasi. Perolehan anggaran didasarkan pada usulan anggaran yang disusun berdasarkan kebutuhan rutin dan pembangunan. Proses penyusunan anggaran merupakan proses penetapan peran, dimana pihak-pihak yang berkaitan diberi peran untuk melaksanakan kegiatan pencapaian sasaran yang ditetapkan dalam anggaran. Dalam proses pembuatan anggaran terdapat dua sistem yaitu, top down dan bottom up.

SDM (Sumber Daya manusia) juga penting dalam organisasi. . Dimana SDM sangat dibutuhkan dalam suatu organisasi untuk sebuah kemajuan organisasi tersebut. Sumber daya manusia dalam suatu organisasi merupakan penentu yang sangat penting bagi keefektifan berjalannya kegiatan di dalam organisasi. Keberhasilan dan kinerja seseorang dalam suatu bidang pekerjaan banyak ditentukan oleh tingkat kompetensi, profesionalisme dan juga komitmennya terhadap bidang pekerjaan yang ditekuninya. Sebuah organisasi dituntut untuk mampu meningkatkan kualitas sumber daya manusia yang ada. Kualitas sumber daya manusia banyak ditentukan oleh sejauh mana sistem yang ada di organisasi atau perusahaan.

Tinggi rendahnya tingkat kepusan kerja yang dirasakan oleh karyawan akan mempengaruhi komitmen karyawan terhadap organisasi, dan komitmen itu akan berpengaruh terhadap kepuasan kerja karyawan yang bersangkutan. Karyawan yang merasa puas akan lebih mungkin terlibat dalam organisasi yang dapat meningkatkan produktivitas, sedangkan karyawan yang tidak merasa puas maka akan mempengaruhi berjalannya organisasi dalam pencapaian tujuan. Menurut Robert L. Mathis \& John H. jackson (2001:99) meskipun kepuasan kerja itu menarik dan penting, hal yang paling mendasar adalah pengaruh kepuasan kerja terhadap organisasi yang akan mempengaruhi kinerja karyawan.

Penelitian ini relatif sama dengan banyak penelitian sebelumnya diantaranya penelitian dari Eris Dianawati (2009) dan Dwi Astuti (2013). Perbedaan penelitian ini dengan penelitian sebelumnya adalah terdapat pada variabel dan objek penelitian. Pada penelitian Eris Dianawati (2009) variabelnya adalah partisipasi penyusunan anggaran, kinerja organisasi dan job related stress, dan objek penelitian tesebut adalah lembaga pendidikan technos di Jawa Timur dengan sampel para kepala cabang. Penelitian Dwi Astuti (2013) variabelnya adalah partisipasi penyusunan anggaran, kinerja manajerial dan komitmen organisasi, dan objek penelitiannya adalah Perusahaan Air Minum Daerah (PDAM) se Karesidenan Surakarta yang pemilihan sampelnya berdasarkan teknik convenience sampling. Sedangkan variabel dalam penelitian ini adalah partisipasi penyusunan anggaran, kepuasan kerja, komitmen organisasi dan kinerja organisasi, dan objek penelitian adalah Dinas Kebudayaan, Pariwisata, 
Kepemudaan dan Olahraga Kabupaten Barito Timur dengan sampel seluruh Pegawai Negeri Sipil pada dinas tersebut.

Tujuan dari penelitian ini adalah untuk mengetahui dan menganalisis mengenai (1) Pengaruh Simultan Partisipasi penyusunan anggaran, kepuasan kerja dan komitmen organisasi terhadap kinerja organisasi, (2) Pengaruh yang signifikan secara parsial partisipasi penyusunan anggaran, kepuasan kerja dan komitmen organisasi terhadap kinerja organisasi, (3) variabel apa yang dominan mempengaruhi kinerja organisasi pada Dinas Kebudayaan, Pariwisata, Kepemudaan dan Olahraga Kabupaten Barito Timur.

\section{Kajian Literatur}

Untuk penelitian ini sudah terdapat beberapa penelitian terdahalu diantaranya yang dilakukan oleh Eris Dianawati (2009) yang meneliti tentang Pengaruh Partisipasi Penyusunan Anggaran Terhadap Kinerja Manajerial: Komitmen Organisasi Dan Job Related Stress Sebagai Variabel Intervening. Populasi ini adalah lembaga pendidikan Technos di Jawa Timur sejumlah 60 buah kantor cabang. Dari 60 buah kantor cabang lembaga pendidikan Primagama di Jawa Timur ternyata hanya 54 yang memiliki kepala cabang dan yang dapat dijadikan sampel. Model analisis yang digunakan dalam penelitian ini adalah Analisis Jalur (Path Analysis). Hasil studi ini mengindikasikan bahwa komitmen organisasi dan job-related stress merupakan variabel penting untuk pencapaian prestasi kinerja manajerial yang baik. Prestasi yang diartikan sebagai keterlibatan dan pengaruh manajer dalam menentukan anggarannya, memberikan dampak positif untuk menumbuhkan komitmen terhadap organisasi tempat mereka bekerja.

Dwi Astuti (2013) meneliti tentang Pengaruh Partisipasi penyusunan anggaran terhadap kinerja manajerial dengan komitmen organisasi sebagai variabel moderating. Populasi dalam penelitian ini adalah perusahaan daerah air minum Se Karesidenan Surakarta. Jumlah sampel yang diambil dalam penelitian ini adalah 57 orang dan diambil dengan teknik convenience Sampling. Hasil pengujian hipotesis pertama menunjukkan bahwa, partisipasi penyusunan anggaran berpengaruh signifikan terhadap kinerja manajerial. Hasil pengujian hipotesis kedua menunjukkan bahwa interaksi antara partisipasi penyusunan anggaran dengan komitmen organisasi berpengaruh terhadap kinerja manajerial.

Yogi Andrianto (2008) Analisis Pengaruh Partisipasi Penyusunan Anggaran Terhadap Kinerja Manajerial Dengan Kepuasan Kerja, Job Relevant Information Dan Kepuasan Kerja Sebagai Variabel Moderating. Populasi dalam penelitian ini adalah seluruh manajer dan kepala bagian yang terlibat dalam proses penyusunan anggaran di rumah sakit swasta di wilayah kota Semarang. Diwilayah kota Semarang terdapat 24 rumah sakit swasta dengan jumlah manajer dan kepala bagian sebanyak 480 orang. Hasil penelitian menunjukkan bukti bahwa partisipasi penyusunan anggaran dengan kinerja manajerial mempunyai hubungan positif dan signifikan. Hasil penelitian ini menunjukkan bahwa interaksi antara partisipasi penyusunan anggaran dan variabel moderating kepuasan kerja berpengaruh pada kinerja manajerial Kemudian interaksi antara partisipasi penyusunan anggaran dan variabel moderating job relevan information kinerja manajerial. Begitu juga hasil penelitian mengenai interaksi antara partisipasi penyusunan anggaran dan variabel moderating motivasi kerja berpengaruh pada kinerja manajerial.

Purwanto (2009) melakukan penelitian tentang pengaruh partisipasi penyusunan anggaran terhadap kinerja pemerintah daerah dengan keadilan distributif, keadilan prosedural, dan goal commitment sebagai variabel moderating. Populasi penelitian ini adalah semua pejabat pengelolaan keuangan daerah yang ada di kabupaten Banjarnegara yaitu Sekertariat Daerah, Bapeda, Sekertariat Dewan, 15 Dinas Teknis dan 4 kantor di Kabupaten Banjarnegara sejumlah 130 responden. Hasil menunjukkan bahwa partisipasi dalam penyusunan anggaran mempunyai pengaruh yang signifikan terhadap kinerja pengelolaan keuangan daerah. Dengan 
adanya pengaruh menunjukkan semakin tinggi partisipasi dalam penyusunan anggaran semakin tinggi pula kinerja pengelolaan keuangan daerah.

Kadek Juli Suwardana dan I Ketut Suryanawa (2008), melakukan penelitian tentang pengaruh partisipasi penyusunan anggaran pada kinerja manajerial dengan komitmen organisasi sebagai variabel moderasi. Populasi penelitian berjumlah 240 orang. Hasilnya menunjukan bahwa partisipasi anggaran secara signifikan dan positif mempengaruhi, komitmen organisasi tidak dapat memperkuat hubungan antara partisipasi anggaran dan kinerja manajerial.

Andarias Bangun (2009), melakukan penelitian tentang pengaruh partisipasi penyusunan anggaran, kejelasan sasaran anggaran dan struktur desentralisasi terhadap kinerja manajerial SKPD dengan pengawasan internal sebagai variabel pemoderasi. Penelitian ini di lakukan pada Kabupaten Deli Serdang dengan mengambil 31 SKPD dan sebanyak 53 SKPD yang ada. Hasil dari penelitiannya adalah secara stimulan seluruh variabel independen berpengaruh terhadap kinerja manajerial SKPD, dan hasil analisa secara parsial terdapat satu variabel independen yang tidak berpengaruh terhadap kinerja managerial SKPD yaitu tentang kejelasan sasaran anggaran. Begitu juga didapat bahwa pengawasan internal tidak apat memoderasi pengaruh partisipasi dalam penyusunan anggaran, kejelasan sasaran anggaran, dan struktur desentralisasi terhadap kinerja manajerial SKPD.

\section{Metode Penelitian}

Populasi dan sampel dalam penelitian ini adalah seluruh Pegawai Negeri Sipil yang ada pada Dinas Kebudayaan, Pariwisata, Kepemudaan dan Olahraga Kabupaten Barito Timur yang berjumlah 40 orang.

Ada 4 variabel yang digunakan dalam penelitian ini yang meliputu partisipasi penyusunan anggaran, kepuasan kerja, komitmen organisasi dan kinerja organisasi. Partisipasi penyusunan anggaran merupakan ciri penyusunan anggaran yang menekankan kepada partisipasi seluruh anggota organisasi untuk turut serta dalam penyusunan dan mentukan anggaran yang akan dijadikan tolak ukur dalam penilaian kinerja organisasi. Variabel partisipasi penyusunan anggaran diukur dengan menggunakan skala LIKERT antara 1 sampai dengan 5. Skor terendah (1) dari jawaban responden menunjukkan rendahnya partisipasi penyusunan anggaran dan skor tinggi (5) menunjukkan tingginya partisipasi penyusunan anggaran. Instrumen pertanyaan tersebut antara lain mengenai: tingkat keterlibatan anggota organisasi dalam penyusunan anggaran, pengaruh yang dimiliki dari anggota organisasi dalam menetukan nilai akhir anggaran, pendapat dan saran dalam penyusunan rencana kegiatan dan anggaran, besarnya pengaruh usulan dan pemikiran, dan seberapa besarnya kontribusi dalam wilayah pertanggung jawaban.

Kepuasan kerja adalah dampak emosional yang dirasakan oleh setiap individu atas keinginan dan harapan yang ingin dicapainya dalam pekerjaannya yang telah terpenuhi. Kepuasan kerja merupakan hal yang bersifat individual. Masing-masing individu organisasi pasti memiliki tingkat kepuasan yang berbeda-beda. Variabel kepuasan kerja diukur dengan menggunakan skala LIKERT antara 1 sampai dengan 5. Skor terendah (1) dari jawaban responden menunjukkan rendahnya tingkat kepuasan kerja, sebaliknya skor tinggi (5) menunjukkan tingginya tingkat kepuasan kerja. Pertanyaan untuk mengukur kepuasan kerja menggunakan dua belas pertanyaan yang berkaitan dengan kepuasan kerja yang ada dalam pribadi seseorang.

Komitmen organisasi merupakan suatu keadaan dimana seorang individu memihak organisasi serta tujuan-tujuan dan keinginannya untuk mempertahankan keangotaannya dalam organisasi. Komitmen organisasi diukur dengan enam pertanyaan dengan skala 1 sampai 5 dimana skala terendah adalah poin 1 dan tertinggi adalah poin 5 . 
Kinerja organisasi merupakan gambaran mengenai tingkat pencapaian pelaksanaan suatu kegiatan/program/kebijakan dalam mewujudkan sasaran, tujuan, misi, dan visi organisasi yang tertuang dalam strategic planning suatu organisasi (Mahsun, 2006 :25). Kinerja organisasi terdiri dari lima pertanyaan dengan skala 1 sampai 5 dimana skala terendah adalah poin 1 dan tertinggi adalah poin 5 .

Sebelum data diolah dan dianalisis, maka terlebih dahulu harus dilakukan pengujian untuk mengetahui kesungguhan para responden dalam menjawab pertanyaan. Pengujian tersebut adalah pengujian validitas (test of validity) dan pengujian reliabilitas (test of reliability).

Pertama Pengujian Validitas. Pengujian validitas dilakukan untuk mengetahui apakah alat ukur yang ada (disusun) valid atau tidak (Ghozali, 2002). Hasil pengujian validitas ditunjukkan oleh suatu indeks yang menjelaskan seberapa jauh suatu alat ukur benar-benar mengukur apa yang perlu diukur Dengan kata lain suatu kuesioner dikatakan valid jika pertanyaan pada kuesioner mampu untuk mengungkapkan suatu yang akan diukur oleh kuesioner tersebut. Uji validitas bertujuan untuk melihat ketepatan instrumen pengukur dalam penelitian. Pengujian ini untuk mengetahui ketepatan instrumen penelitian agar dapat memberikan informasi yang akurat tentang hal yang diukur. Uji Validitas dilakukan dengan cara melihat korelasi antara skor butir pertanyaan dengan total skor variabel melalui program SPSS. Dasar pengambilan keputusan adalah jika nilai $r$ hitung $>r$ tabel.

Kedua Uji Reliabilitas. Pengujian reliabilitas dilakukan hanya pada pertanyaanpertanyaan yang telah melalui pengujian validitas, dan yang dinyatakan valid. Pengujian ini untuk mengetahui sejauh mana hasil pengukuran terhadap item-item pertanyaan apakah tetap konsisten bila dilakukan pengukuran dua atau lebih terhadap gejala yang sama dengan alat ukur yang sama. Hasil pengujian reliabilitas ditunjukkan dalam suatu indeks yang menjelaskan seberapa jauh suatu alat ukur dapat dipercaya atau diandalkan.

Ketiga Pengujian Data. Data diuji dengan uji regresi linear berganda dan dilakukan uji asumsi klasik. Pengujian Linear Berganda dalam persamaan regresi berikut:

$$
\mathrm{Y}=\mathrm{a}+\mathrm{b} 1 \mathrm{X} 1+\mathrm{b} 2 \mathrm{X} 2+\mathrm{b} 3 \mathrm{X} 3+\mathrm{e}
$$

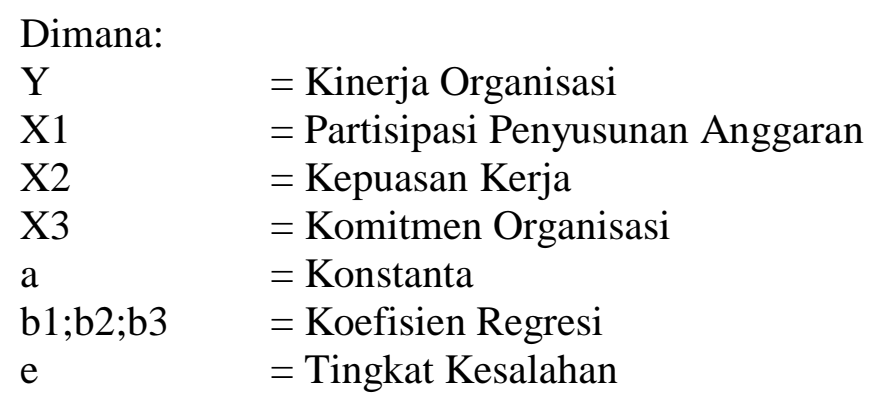

\section{Hasil Penelitian dan Pembahasan}

Dari hasil uji validitas keseluruhan item pertanyaan pada variabel partisipasi penyusunan anggaran, kepuasan kerja, komitmen organisasi dan kinerja organisasi mempunyai nilai $r$ hitung (Corrected Item-Total Correlation) $>r$ tabel $(0,3120)$ sehingga dapat dikatakan bahwa seluruh item pertanyaan pada variabel penelitian ini adalah valid.

Hasil uji reliabilitas menyatakan bahwa partisipasi penyusunan anggaran mempunyai koefisien Cronbach's Alpha sebesar 0,881, kepuasan kerja mempunyai koefisien Cronbach's Alpha sebesar 0,949, komitmen organisasi mempunyai koefisien Cronbach's Alpha sebesar 0,909, dan kinerja organisasi mempunyai koefisien Cronbach's Alpha sebesar 0,929 yang artinya semua variabel di atas 0,8 maka dapat disimpulkan bahwa instrumen yang digunakan di dalam penelitian ini adalah reliabel. 
Dari hasil pengujian validitas dan reliabilitas, maka dapat disimpulkan bahwa angket partisipasi penyusunan anggaran, kepuasan kerja, komitmen organisasi dan kinerja organisasi sudah layak untuk digunakan sebagai instrumen penelitian.

Berdasarkan desain penelitian maka sumber informasi yang diperoleh dari pegawai dideskripsikan dalam bentuk nilai minimum, nilai maksimum, rata-rata dan standar deviasi yang dapat dilihat pada tabel 1 .

Tabel 1. Statistik Deskriptif Variabel Penelitian

\begin{tabular}{lrrrrr}
\hline & $\begin{array}{c}\text { Partisipasi penyusunan } \\
\text { anggaran }\end{array}$ & $\begin{array}{c}\text { Kepuasan } \\
\text { kerja }\end{array}$ & $\begin{array}{c}\text { Komitmen } \\
\text { organisasi }\end{array}$ & \multicolumn{1}{c}{$\begin{array}{c}\text { Kinerja } \\
\text { organisasi }\end{array}$} \\
\hline $\mathrm{N}$ & Valid & 40 & 40 & 40 & 40 \\
\cline { 2 - 7 } Missing & 0 & 0 & 0 & 0 \\
\hline Mean & 11,45 & 27,13 & 13,78 & 13,45 \\
\hline Median & 11,00 & 25,50 & 13,50 & 12,00 \\
\hline Std. Deviation & 4,930 & 11,523 & 5,972 & 6,168 \\
\hline Variance & 24,305 & 132,779 & 35,666 & 38,049 \\
\hline Range & 17 & 41 & 21 & 20 \\
\hline Minimum & 5 & 12 & 6 & 5 \\
\hline Maximum & 22 & 53 & 27 & 25 \\
\hline
\end{tabular}

Berdasarkan Tabel 1 diketahui bahwa tanggapan responden terhadap variabel penelitian dinilai baik.

1. Variabel independen partisipasi penyusunan anggaran dengan nilai mean sebesar 11,45. Nilai maksimum sebesar 22. Nilai minimum sebesar 5. Dengan standar deviasi sebesar 4.930 yang berarti bahwa besar peningkatan maksimum rata-rata variabel pasrtisipasi penyusunan anggaran sebesar +4.930 , sedangkan penurunan maksimum dari rata-rata variabel partisipasi penyusunan anggaran sebesar -4.930 .

2. Variabel kepuasan kerja dengan nilai mean sebesar 27,13. Nilai maksimum sebesar 53 . Nilai minimum sebesar 12. Dengan standar deviasi sebesar 11,523 yang berarti bahwa besar peningkatan maksimum rata-rata variabel kepuasan kerja sebesar $+11,523$, sedangkan penurunan maksimum rata-rata variabel kepuasan kerja sebesar -11,523.

3. Variabel komitmen organisasi dengan nilai mean sebesar 13,78. Nilai maksimum sebesar 27. Nilai minimum sebesar 6. Dengan standar deviasi sebesar 5,972 yang berarti bahwa besar peningkatan maksimum rata-rata variabel komitmen organisasi sebesar $+5,972$, sedangkan penurunan maksimum rata-rata variabel komitmen organisasi -5,972.

4. Variabel kinerja organisasi sebagai variabel dependen memiliki nilai mean atau rataratanya sebesar 13,45. Nilai maksimum sebesar 25 dan nilai minimum sebesar 5. Dengan standar deviasi sebesar 6,168 yang berarti bahwa besar peningkatan maksimum dari ratarata variabel kinerja organisasi Dinas Kebudayaan, Pariwisata, Kepemudaan dan olahraga Kabupaten Barito Timur adalah $+6,168$, sedangkan besarnya penurunan dari rata-rata variabel kinerja organisasi Dinas Kebudayaan, Pariwisata, Kepemudaan dan olahraga Kabupaten Barito Timur adalah -6,168.

Tabel 1 juga menunjukkan bahwa variabel kepuasan kerja merupakan variabel penelitian yang paling banyak mendapatkan tanggapan positif dari responden penelitian. Item pertanyaan dari variabel kepuasan kerja lebih mudah dipahami oleh responden sehingga ratarata hasil tanggapan responden terhadap variabel kepuasan kerja merupakan rata-rata nilai tertinggi dari variabel penelitian yang lainnya. 
Awalliyah, Penyusunan Anggaran, Kepuasan Kerja, dan Komitmen Organisasi Terhadap Kinerja ...

Tabel 2. Uji Multikolinieritas

\begin{tabular}{|c|c|c|c|c|c|c|c|c|}
\hline \multirow{2}{*}{\multicolumn{2}{|c|}{ Model }} & \multicolumn{2}{|c|}{$\begin{array}{l}\text { Unstandardized } \\
\text { Coefficients }\end{array}$} & \multirow{2}{*}{$\begin{array}{c}\text { Standardized } \\
\text { Coefficients }\end{array}$} & \multirow[t]{2}{*}{$\mathrm{t}$} & \multirow[t]{2}{*}{ Sig. } & \multicolumn{2}{|c|}{$\begin{array}{l}\text { Collinearity } \\
\text { Statistics }\end{array}$} \\
\hline & & B & Std. Error & & & & Tolerance & VIF \\
\hline \multirow[t]{4}{*}{1} & (Constant) & 1,007 & 1,180 & & ,853 & ,399 & & \\
\hline & $\begin{array}{l}\text { Partisipasi } \\
\text { penyusunan } \\
\text { anggaran }\end{array}$ & 3,693 & 1,421 & 2,951 & 2,598 & ,013 & ,004 & 231,017 \\
\hline & $\begin{array}{l}\text { Kepuasan } \\
\text { kerja }\end{array}$ &,- 287 & ,319 &,- 535 &,- 898 & ,375 & ,016 & 63,633 \\
\hline & $\begin{array}{l}\text { Komitmen } \\
\text { organisasi }\end{array}$ & $-1,602$ & ,770 & $-1,551$ & $-2,081$ & ,045 & ,010 & 99,4 \\
\hline
\end{tabular}

a. Dependent Variable: kinerja organisasi

Berdasarkan Tabel 2 diketahui bahwa VIF dari hasil uji asumsi klasik masih diantara diatas 10 maka tidak terjadi multikolinieritas.

Tabel 3. Uji Autokorelasi

\begin{tabular}{lccccr}
\hline Model & $\mathrm{R}$ & $\mathrm{R}$ Square & $\begin{array}{c}\text { Adjusted R } \\
\text { Square }\end{array}$ & $\begin{array}{c}\text { Std. Error of the } \\
\text { Estimate }\end{array}$ & Durbin-Watson \\
\hline 1 &, $894^{\mathrm{a}}$ &, 799 &, 782 & 2,879 & 1,269 \\
\hline $\begin{array}{l}\text { a. Predictors: (Constant), komitmen organisasi, kepuasan kerja, partisipasi penyusunan } \\
\text { anggaran }\end{array}$ & & \\
\hline
\end{tabular}

Berdasarkan Tabel 3 diketahui bahwa jika nilai Durbin Watson pada tabel Durbin watson $(\mathrm{k}, \mathrm{n})$ jadi $(3,40)$ diperoleh nilai du dan dl yaitu 1,6589 dan 1,3384 maka nilai autokorelasi diantara 1,6589 >1,269 $<2,3411$ jadi tidak terjadi autokorelasi. Sehingga dapat diambil kesimpulan bahwa model regresi yang digunakan dinyatakan terdapat variabel pengganggu penyebab terjadi autokorelasi. Penyebab autokorelasi adalah estimator yang dihasilkan masih unbiased, konsisten, dan asymptotical normally distributed, estimasi standard error dan varian koefisien regresi yang didapat akan'underestimate' dan pemeriksaan terhadap residulnya akan menemui permasalahan. Autokorelasi yang kuat akan pula menyebabkan dua variabel yang tidak berhubungan menjadi berhubungan yang disebut spourious regression dan hal ini terlihat dari $\mathrm{R}^{2}$.

Tabel 4. Uji Normalitas

\begin{tabular}{|c|c|c|c|c|c|c|}
\hline \multicolumn{7}{|c|}{ Tests of Normality } \\
\hline & \multicolumn{3}{|c|}{ Kolmogorov-Smirnov $^{\mathrm{a}}$} & \multicolumn{3}{|c|}{ Shapiro-Wilk } \\
\hline & $\begin{array}{l}\text { Statisti } \\
\text { c }\end{array}$ & Df & Sig. & $\begin{array}{l}\text { Statisti } \\
\text { c }\end{array}$ & Df & Sig. \\
\hline Kinerja organisasi &, 137 & 40 &, 056 & ,916 & 40 & ,006 \\
\hline $\begin{array}{l}\text { Partisipasi penyusunan } \\
\text { anggaran }\end{array}$ & ,156 & 40 & ,016 & ,908 & 40 & ,003 \\
\hline kepuasan kerja &, 135 & 40 & ,066 & 918, & 40 & ,007 \\
\hline Komitmen organisasi &, 111 & 40 & $200^{*}$ & ,923 & 40 &, 010 \\
\hline
\end{tabular}


Berdasarkan tabel 4 diatas dapat kita lihat bahwa nilai signifikan pada kolom Kolmogorov-Smirnov pada variabel partisipasi penyusunan anggaran mempunyai nilai signifikan dibawah 0,05 sehingga dapat dikatakan bahwa data berdistribusi tidak normal atau H0 diterima, dengan kata lain bahwa sebaran data penelitian variabel partisipasi penyusunan anggaran tidak berdistribusi normal. Sedangkan nilai nilai signifikan pada kolom Kolmogorov-Smirnov pada variabel kepuasan kerja, komitmen organisasi dan kinerja organisasi mempunyai nilai signifikan diatas 0,05 sehingga dapat dikatakan bahwa data berdistribusi normal atau $\mathrm{H} 0$ ditolak, dengan kata lain bahwa sebaran data penelitian variabel kepuasan kerja dan komitmen organisasi berdistribusi normal.

\section{Tabel 5. Uji Linearitas}

\begin{tabular}{|c|c|c|c|c|c|c|c|}
\hline \multicolumn{8}{|c|}{ ANOVA Table } \\
\hline & & & $\begin{array}{l}\text { Sum of } \\
\text { Squares }\end{array}$ & df & $\begin{array}{l}\text { Mean } \\
\text { Square }\end{array}$ & $\mathrm{F}$ & Sig. \\
\hline \multirow{5}{*}{$\begin{array}{l}\text { Kinerja } \\
\text { organisasi * } \\
\text { partisipasi } \\
\text { penyusunan } \\
\text { anggaran }\end{array}$} & \multirow{3}{*}{$\begin{array}{l}\text { Between } \\
\text { Groups }\end{array}$} & (Combined) & 1243,783 & 13 & 95,676 & 10,360 & ,000 \\
\hline & & Linearity & 1149,623 & 1 & 1149,623 & 124,482 &, 000 \\
\hline & & $\begin{array}{l}\text { Deviation from } \\
\text { Linearity }\end{array}$ & 94,161 & 12 & 7,847 &, 850 & ,603 \\
\hline & \multicolumn{2}{|c|}{ Within Groups } & 240,117 & 26 & 9,235 & & \\
\hline & \multicolumn{2}{|c|}{ Total } & 1483,900 & 39 & & & \\
\hline
\end{tabular}

Berdasarkan tabel 5 diatas dapat kita lihat bahwa nilai signifikan adalah tidak terlihat. Bila $\alpha$ yang ditentukan adalah 5\%, maka berdasarkan keluaran di atas, dapat disimpulkan bahwa data yang dipergunakan dapat dijelaskan oleh regresi linier dengan kurang baik karena nilai Sig. linearity data tersebut adalah sebesar 0,000 (lebih kecil dari 0,05) dan nilai nilai Sig. deviation from linearity data adalah 0,603 (lebih besar dari 0,05) sehingga dapat dikatakan bahwa data penelitian variabel adalah linear.

Hasil analisis regresi linear berganda yang dihitung dengan menggunakan program SPSS 24 dapat dilihat pada tabel 6 dan 7.

Tabel 6. Uji Regresi Linier Secara Simultan

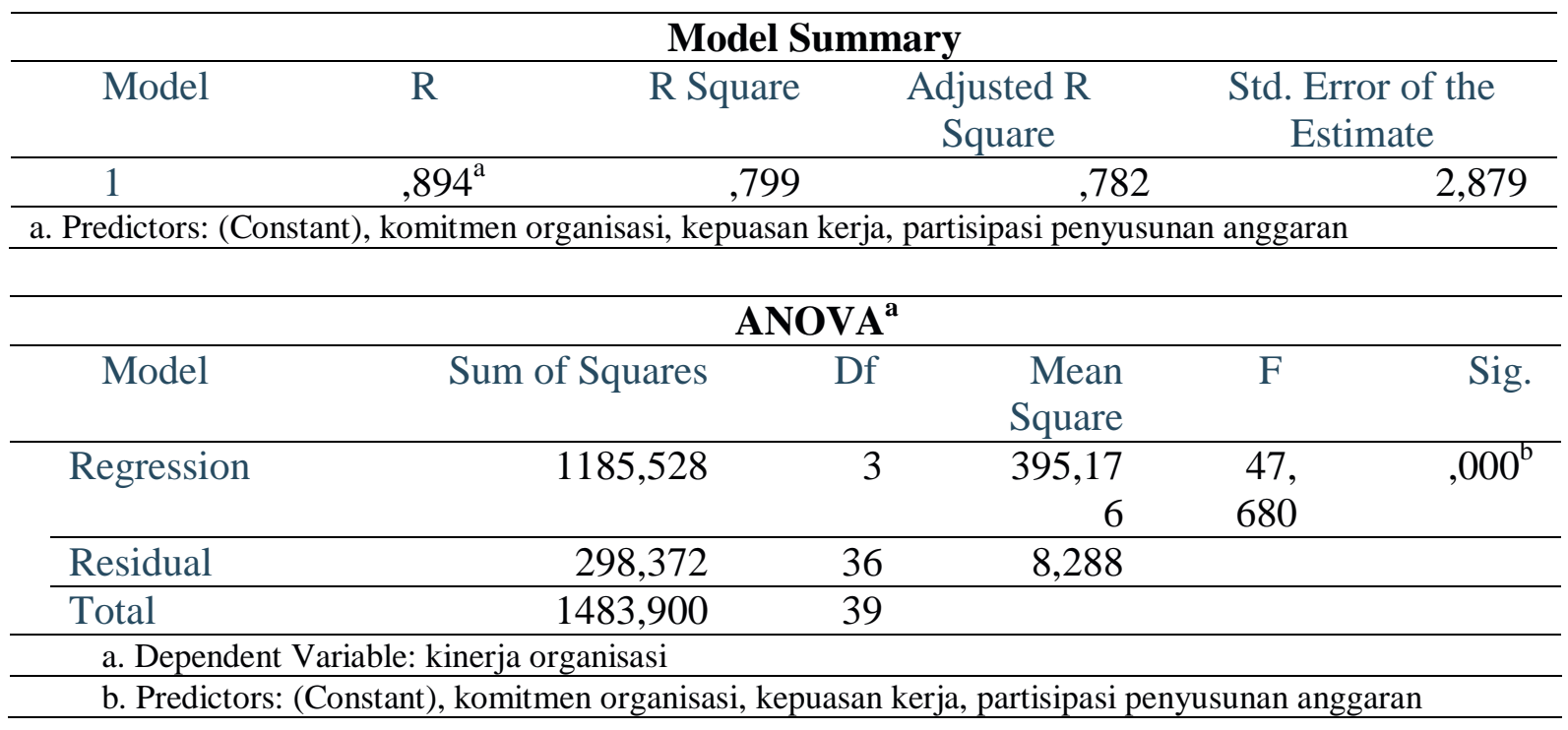


Awalliyah, Penyusunan Anggaran, Kepuasan Kerja, dan Komitmen Organisasi Terhadap Kinerja ....

Tabel 7. Uji Regresi Linier Secara Parsial

\begin{tabular}{|c|c|c|c|c|c|c|}
\hline \multirow{2}{*}{\multicolumn{2}{|c|}{ Model }} & \multicolumn{2}{|c|}{$\begin{array}{l}\text { Unstandardized } \\
\text { Coefficients }\end{array}$} & \multirow{2}{*}{$\begin{array}{c}\text { Standardized } \\
\text { Coefficients } \\
\text { Beta }\end{array}$} & \multirow[t]{2}{*}{$\mathrm{t}$} & \multirow[t]{2}{*}{ Sig. } \\
\hline & & $\mathrm{B}$ & Std. Error & & & \\
\hline \multirow[t]{4}{*}{1} & (Constant) & 1,007 & 1,180 & & ,853 & ,399 \\
\hline & $\begin{array}{l}\text { Partisipasi penyusunan } \\
\text { anggaran }\end{array}$ & 3,693 & 1,421 & 2,951 & 2,598 & ,013 \\
\hline & Kepuasan kerja &,- 287 & ,319 &,- 535 &,- 898 & ,375 \\
\hline & Komitmen organisasi & $-1,602$ & ,770 & $-1,551$ & $-2,081$ &, 045 \\
\hline
\end{tabular}

Dari hasil analisis dalam Tabel 6 dan Tabel 7, dapat ditulis persamaan regresi sebagai berikut:

$\mathrm{Y}=1,007+3,693 \mathrm{X} 1-0,287 \mathrm{X} 2-1,602 \mathrm{X} 3+\mathrm{e}$

1. Dari model tersebut diperoleh bahwa koefisien regresi linier berganda nilai konstanta 1,007 berarti bahwa jika Partisipasi penyusunan anggaran (x1), Kepuasan kerja (x2) dan Komitmen organisasi (x3) nilainya adalah 0, maka Kinerja organisasi (Y) nilainya adalah 1,007

2. Dari model tersebut diperoleh bahwa koefisien regresi linier berganda, variabel partisipasi penyusunan anggaran bertanda positif sebesar 3,693 yang berarti bahwa jika terjadi peningkatan partisipasi penyusunan anggaran meningkat satu satuan maka kinerja organisasi akan meningkat 3,693 satuan

3. Variabel kepuasan kerja mempunyai nilai koefisien regresi linier berganda sebesar negatif 0,287 yang berarti bahwa jika kepuasan kerja meningkat satu satuan maka kinerja organisasi akan mengalami penurunan sebesar 0,287 satuan.

4. Variabel komitmen organisasi mempunyai nilai koefisien regresi linier berganda sebesar negatif 1,602 yang berarti bahwa komitmen organisasi berpengaruh negatif terhadap kinerja organisasi. Artinya jika komitmen organisasi meningkat satu satuan maka kinerja organisasi akan menurun 1,602 satuan.

5. Untuk menentukan variabel yang memiliki pengaruh yang paling dominan dapat dilihat dari nilai koefisien standardized dari model regresi (Imam Ghozali, 2005). Dalam hal ini diperoleh bahwa variabel partisipasi penyusunan anggaran merupakan variabel yang berpengaruh paling dominan terhadap kinerja organisasi yang ditunjukkan dengan nilai standardized coefficients sebesar positif 2,951 yang paling besar diantara variabel lainnya.

Berdasarkan hasil pengolahan data (yang ditunjukkan pada Tabel 6), diperoleh nilai $\mathrm{F}$ hitung $(47,680)$ lebih besar dari $\mathrm{F}$ tabel $(3,25)$ dan dapat dilihat nilai signifikansi sebesar 0,000 lebih kecil dari 0,05 dengan nilai $\mathrm{R}$ Square sebesar 0,799 sehingga dapat dikatakan bahwa partisipasi penyusunan anggaran, kepuasan kerja dan komitmen organisasi secara bersama-sama berpengaruh terhadap kinerja organisasi pada Dinas Kebudayaan, Pariwisata, Kepemudaan dan Olahraga Kabupaten Barito Timur sebesar 79,9\%. Hal tersebut dapat kita lihat pada tabel 6. Berdasarkan pengujian diatas, maka hipotesis 1 dapat dibuktikan.

Berdasarkan hasil pengujian regresi linear secara parsial yang ada pada tabel 7 dapat dilihat bahwa:

1. Variabel Partisipasi Penyusunan Anggaran.

Diperoleh koefisien regresi linier berganda untuk partisipasi penyusunan anggaran sebesar positif 3,693 dan nilai t hitung sebesar positif 2,598 lebih besar dari t tabel sebesar 2,024 dan nilai signifikansi ( $\mathrm{p}$-value) sebesar 0,013. Terlihat pada p-value (kolom Sig) terlihat nilai sebesar 0,013 (lebih kecil dari 0,05) dengan demikian Ho ditolak maka dapat 
dikatakan partisipasi penyusunan anggaran berpengaruh positif terhadap kinerja organisasi pada Dinas Kebudayaan, Pariwisata, Kepemudaan dan Olahraga Kabupaten Barito Timur.

2. Variabel Kepuasan Kerja.

Diperoleh koefisien regresi linier berganda untuk kepuasan kerja sebesar negatif 0,287 dan nilai t hitung sebesar negatif 0,898 lebih kecil dari t tabel sebesar 2,024 dan nilai signifikansi (p-value) sebesar 0,375. Terlihat pada p-value (kolom Sig) terlihat nilai sebesar 0,375 (lebih besar dari 0,05) dengan demikian Ho ditterima maka dapat dikatakan kepuasan kerja tidak berpengaruh terhadap kinerja organisasi pada Dinas Kebudayaan, Pariwisata, Kepemudaan dan Olahraga Kabupaten Barito Timur.

\section{Variabel Komitmen Organisasi}

Diperoleh koefisien regresi linier berganda untuk komitmen organisasi sebesar negatif 1,602 dan nilai t hitung sebesar negatif 2,081 lebih besar dari t tabel sebesar 2,024 dan nilai signifikansi (p-value) sebesar 0,045. Terlihat pada p-value (kolom Sig) terlihat nilai sebesar 0,045 (lebih kecil dari 0,05) dengan demikian Ho ditolak maka dapat dikatakan komitmen organisasi berpengaruh negatif terhadap kinerja organisasi pada Dinas Kebudayaan, Pariwisata, Kepemudaan dan Olahraga Kabupaten Barito Timur.

Berdasarkan pada ketiga pembuktian tersebut, maka hipotesis 2 tidak sepenuhnya terbukti karena walaupun ada 2 variabel yang berpengaruh signifikan terhadap kinerja organisasi, variabel kepuasan kerja tidak berpengaruh signifikan terhadap kinerja organisasi.

Dari ketiga variabel independen tersebut variabel partisipasi penyusunan anggaran mempunyai nilai koefisien regresi paling besar dibandingkan dengan variabel partisipasi kepuasan kerja dan variabel komitmen organisasi, hal tersebut berarti bahwa variabel partisipasi penyusunan anggaran merupakan variabel paling dominan berpengaruh signifikan terhadap kinerja organisasi, maka hipotesis 3 terbukti.

Hasil pengujian variabel-variabel tersebut dapat dilihat pada skema yang ditunjukkan pada Gambar 2.

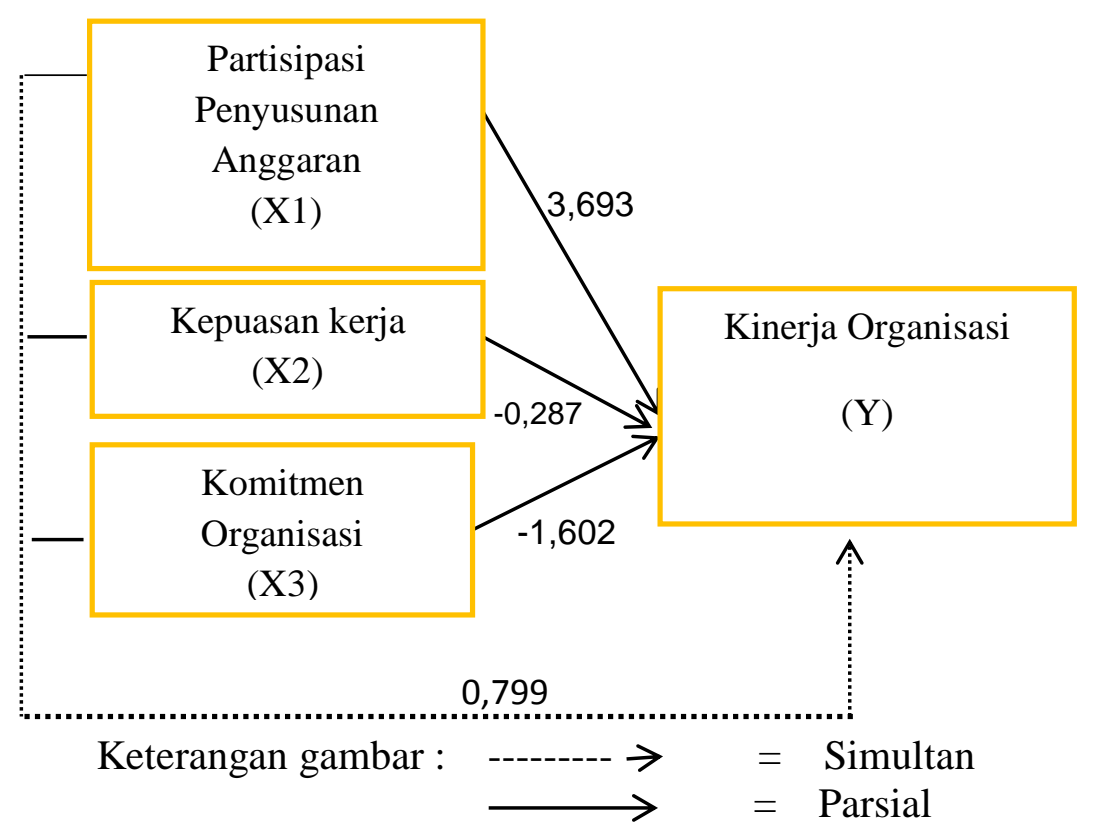

Gambar 2. Rangkuman Analisis 
Dari tabel 6 dapat kita lihat besarnya koefisien determinasi (R square) adalah 0,799. Hal ini berarti bahwa ada pengaruh simultan antara variabel independen terhadap variabel dependen yang besarnya 79,9\%. Besarnya pengaruh partisipasi penyusunan anggaran, kepuasan kerja dan komitmen organisasi secara bersama-sama terhadap kinerja organisasi pada Dinas Kebudayaan, Pariwisata, Kepemudaan dan Olahraga Kabupaten Barito Timur ditunjukkan oleh nilai R square sebesar 0,799. Koefisien determinasi (R square) sebesar 0,799 menunjukkan bahwa partisipasi penyusunan anggaran, kepuasan kerja dan komitmen organisasi secara bersama-sama memiliki kontribusi pengaruh terhadap kinerja organisasi pada Dinas Kebudayaan, Pariwisata, Kepemudaan dan Olahraga Kabupaten Barito Timur sebesar 79,9 Persen. Sedang 20,10 \% lagi dipengaruhi oleh variabel lain diluar variabel penelitian ini. Pada penelitian partisipasi penyusunan anggaran merupakan variabel paling dominan berpengaruh terhadap kinerja organisasi ini dapat dilihat dari Standardized Coefficients Beta sebesar 2,951.

Tujuan penelitian adalah untuk mengetahui pengaruh partisipasi penyusunan anggaran, kepuasan kerja dan komitmen organisasi terhadap kinerja organisasi pada Dinas Kebudayaan, Pariwisata, Kepemudaan dan Olahraga Kabupaten Barito Timur, secara simultan maupun parsial. Partisipasi penyusunan anggaran, kepuasan kerja dan komitmen organisasi berpengaruh secara simultan terhadap kinerja organisasi pada Dinas Kebudayaan, Pariwisata, Kepemudaan dan Olahraga Kabupaten Barito Timur. Berdasarkan hasil analisis dinyatakan bahwa partisipasi penyusunan anggaran, kepuasan kerja dan komitmen organisasi secara simultan berpengaruh positif terhadap kinerja organisasi pada Dinas Kebudayaan, Pariwisata, Kepemudaan dan Olahraga Kabupaten Barito Timur. Hal tersebut dibuktikan dengan hasil RSquare sebesar 0,799. Dari hasil pengujian secara statistik adalah bermakna dan dapat dikatakan bahwa partisipasi penyusunan anggaran, kepuasan kerja dan komitmen organisasi secara simultan berpengaruh sebesar 79,9\% terhadap kinerja organisasi. Dengan demikian hipotesa pertama yang menyatakan bahwa partisipasi penyusunan anggaran, kepuasan kerja dan komitmen organisasi berpengaruh simultan terhadap kinerja organisasi pada Dinas Kebudayaan, Pariwisata, Kepemudaan dan Olahraga adalah terbukti. Seseorang akan semakin merasa puas dengan pekerjaannya, semakin taat terhadap organisasinya, semakin termotivasi dan semakin bagus kepemimpinannya, maka akan semakin meningkat kinerjanya di organisasinya (Supartini, 2015).

Pengaruh parsial partisipasi penyusunan anggaran, kepuasan kerja dan komitmen organisasi terhadap kinerja organisasi pada Dinas Kebudayaan, Pariwisata, Kepemudaan dan Olahraga Kabupaten Barito Timur dapat dijabarkan sebagai berikut:

1. Pengaruh Partisipasi Penyusunan Anggaran Terhadap Kinerja Organisasi.

Partisipasi penyusunan anggaran berpengaruh parsial terhadap kinerja organisasi pada Dinas Kebudayaan, Pariwisata, kepemudaan dan Olahraga Kabupaten Barito Timur. Hal tersebut dibuktikan dengan hasil signifikansi lebih kecil dari signifikansi dengan tingkat kepercayaan $95 \%$ dan koefisien regresi sebesar positif 2,951. Dari hasil pengujian koefisien jalur dari X1 ke Y secara statistik adalah bermakna yang menunjukkan bahwa variabel partisipasi penyusunan anggaran berpengaruh positif terhadap kinerja organisasi yang berarti bahwa semakin tinggi partisipasi penyusunan anggaran pada Dinas Kebudayaan, Pariwisata, Kepemudaan dan Olahraga Kabupaten Barito Timur maka semakin tinggi kinerja organisasi. Dengan demikian hipotesa kedua yang menyatakan bahwa partisipasi penyusunan anggaran berpengaruh parsial terhadap kinerja organisasi pada Dinas Kebudayaan, Pariwisata, Kepemudaan dan Olahraga adalah terbukti. Hal ini berarti bahwa dengan adanya partisipasi penyusunan anggaran akan lebih mendorong bagi para atasan untuk meningkatkan kinerjanya sehingga sasaran dan target yang telah ditetapkan akan tercapai. Partisipasi penyusunan anggaran merupakan keterlibatan kepala dinas, sekretaris, kabid, kepala sub bagian, kepala sub bidang dan bawahan dalam 
pencapaian sasaran yang telah ditetapkan dalam anggaran. Dinas Kebudayaan, Pariwisata, Kepemudaan dan Olahraga Kabupaten Barito Timur memiliki tingkat partisipasi yang tinggi. Budi Hartono Kusuma (Jurnal Akuntansi Vol.8) menyatakan bahwa partisipasi penyusunan anggaran berpengaruh positif terhadap kinerja manajerial. Hal ini membuktikan bahwa semakin tinggi derajat keterlibatan dalam proses penyusunan anggaran maka semakin tinggi pula kinerja manajerial yang dihasilkan. Hasil penelitian Soleha et al. (2013) berhasil membuktikan bahwa kinerja pemerintah meningkat seiring dengan tingginya tingkat partisipasi dalam penyusunan anggaran.

2. Pengaruh kepuasan kerja terhadap kinerja organisasi.

Kepuasan kerja tidak berpengaruh parsial terhadap kinerja organisasi pada Dinas Kebudayaan, Pariwisata, Kepemudaan dan Olahraga Kabupaten Barito Timur. Hal tersebut dibuktikan dengan hasil signifikansi sebesar 0,375 (lebih besar dari 0,05) dengan tingkat kepercayaan 95\%. Dari hasil pengujian koefisien jalur dari X2 ke Y secara statistik adalah tidak bermakna yang menunjukkan bahwa tidak adanya hubungan antara variabel kepuasan kerja dengan kinerja organisasi pada Dinas Kebudayaan, Pariwisata, Kepemudaan dan Olahraga Kabupaten Barito Timur. Dengan demikian hipotesa kedua yang menyatakan bahwa kepuasan kerja berpengaruh parsial terhadap kinerja organisasi pada Dinas Kebudayaan, Pariwisata, Kepemudaan dan Olahraga Kabupaten Barito Timur adalah tidak terbukti. Hal ini berarti bahwa walaupun kepuasan kerja para pegawai pada Dinas Kebudayaan, Pariwisata, Kepemudaan dan Olahraga Kabupaten Barito Timur tercapai, akan tetapi tidak berpengaruh terhadap kinerja organisasi dan begitu juga sebaliknya. Karena kepuasan kerja bukanlah hal utama yang menjadi pendorong untuk dia meningkatkan kinerjanya akan tetapi ada faktor lain seperti kewajiban untuk melaksanakan tugas sesuai tupoksi dari masing-masing pegawai dan pentingnya sebuah pekerjaan. Hasil penelitian ini sesuai dengan penelitian sebelumnya yaitu penelitian yang dilakukan oleh Mahmud Ali (2013) Strategi penelitian pendidikan. Ivancevich (2008:12), menyebutkan bahwa kepuasan karyawan tidak secara otomatis dapat meningkatkan produktivitas, walaupun ketidakpuasan karyawan cenderung menurunkan produktivitas, lebih sering mangkir dan menghasilkan kualitas lebih rendah dari pada karyawan yang puas. Pengelolaan SDM yang kurang maksimal dapat mengakibatkan tingkat kepuasan kerja juga kurang maksimal. Jika kepuasan kerja tidak maksimal akan berpengaruh pada pencapaian kinerja organisasi yang kurang maksimal.

3. Pengaruh komitmen organisasi terhadap kinerja organisasi

Komitmen organisasi berpengaruh parsial terhadap kinerja organisasi pada Dinas Kebudayaan, Pariwisata, Kepemudaan dan Olahraga Kabupaten Barito Timur. Hal tersebut dibuktikan dengan hasil signifikansi sebesar 0,045 (lebih kecil dari 0,05) dengan tingkat kepercayaan 95\%. Dari hasil pengujian koefisien jalur dari X2 ke Y secara statistik adalah bermakna yang menunjukkan bahwa adanya hubungan negatif antara variabel komitmen organisasi dengan kinerja organisasi pada Dinas Kebudayaan, Pariwisata, Kepemudaan dan Olahraga Kabupaten Barito Timur. Dengan demikian hipotesa kedua yang menyatakan bahwa komitmen organisasi berpengaruh parsial terhadap kinerja organisasi pada Dinas Kebudayaan, Pariwisata, Kepemudaan dan Olahraga adalah terbukti. Berdasarkan teori komitmen organisasi merupakan komitmen yang dimiliki oleh seorang karyawan terhadap perusahaan dimana karyawan tersebut bekerja. Karyawan yang memiliki komitmen organisasi yang tinggi akan berusaha melibatkan diri untuk dapat memajukan perusahaan. Namun pada penelitian ini diketahui bahwa komitmen organisas berpengaruh signifikan dan negatif terhadap kinerja organisasi. Hal ini berarti bahwa ketika komitmen organisasi meningkat justru akan menurunkan kinerja organisasi. Hal ini dapat dikarenakan terdapat 
faktor-faktor lain yang lebih berpengaruh dalam mempengaruhi kinerja organsasi. Hasil ini mengandung implikasi bahwa organisasi perlu memperhatikan komitmen anggotanya demi keberlangsungan organisasi itu sendiri. Hal ini sesuai hasil penelitian yang dilakukan oleh Hendrawan Qonit Mekta (2017) bahwa terdapat pengaruh negatif komitmen organisasi terhadap kinerja. Komitmen karyawan terhadap organisasi adalah bertingkat, dari tingkatan yang sangat rendah hingga tingkatan yang sangat tinggi. Menurut Streers (1991) dalam Sopiah (2008) karyawan yang berkomitmen rendah akan berdampak pada turnover, tinggi nya absensi, meningkatnya kelambatan kerja dan kurangnya intensitas untuk bertahan sebagai karyawan di organisasi tersebut, rendahnya kualitas kerja dan kurangnya loyalitas pada perusahaan. Near dan Jansen (1983) dalam sopiah (2008) menambahkan bahwa bila komitmen karyawan rendah maka dia bisa memicu perilaku karyawan yang kurang baik, misalnya tindakan kerusuhan yang dampak lebih lanjutnya adalah reputasi organisasi menurun, kehilangan kepercayaan dari klien dan dampak yang lebih jauh lagi adalah menurunnya laba perusahaan.

Partisipasi penyusunan anggaran merupakan variabel yang paling dominan mempengaruhi kinerja organisasi. Hal tersebut dibuktikan dengan hasil koefisien regresi variabel partisipasi penyusunan anggaran yang paling dominan diantara variabel kepuasan kerja dan variabel komitmen organisasi yaitu sebesar positif 2,951 dengan nilai signifikan sebesar 0,013. Dengan demikian hipotesa ketiga yang menyatakan bahwa partisipasi penyusunan anggaran merupakan variabel yang paling dominan mempengaruhi kinerja organisasi adalah terbukti.

Adanya pengaruh positif antara partisipasi penyusunan anggaran terhadap kinerja organisasi menunjukkan bahwa semakin tinggi partisipasi penyusunan anggaran maka akan semakin meningkatkan kinerja organisasi. Hasil penelitian ini konsisten dengan hasil penelitian yang telah dilakukan oleh Fahrianta (2001), Made Pradana (2002) dan Yogi Adrianto (2008). Partisipasi penyusunan anggaran merupakan keterlibatan seluruh manajer dalam suatu lembaga untuk melakukan kegiatan dalam pencapaian sasaran yang telah ditetapkan dalam anggaran. Dengan adanya keterlibatan Ketua program studi dalam penyusunan anggaran akan mendorong mereka untuk bertanggung jawab terhadap tugas yang diembannya, sehingga ketua program studi akan meningkatkan kinerjanya agar mereka dapat mencapai sasaran atau target yang telah ditetapkan dalam anggaran secara maksimal.

Pengaruh dominan terhadap kinerja organisasi pada Dinas Kebudayaan Pariwisata Kepemudaan dan Olahraga Kabupaten Barito Timur.

Pengaruh variabel penelitian mana yang paling dominan berpengaruh terhadap kinerja organisasi pada Dinas Kebudayaan Pariwisata Kepemudaan dan Olahraga Kabupaten Barito Timur. Berdasarkan analisis dinyatakan bahwa partisipasi penyusunan anggaran merupakan variabel yang dominan berpengaruh terhadap kinerja organisasi hal ini bisa dibuktikan dari hasil koefisien regresi linier berganda untuk variabel partisipasi penyusunan anggaran mempunyai nilai koefisien regresi linier berganda paling tinggi yaitu 2,951 dibandingkan variabel kepuasan kerja mempunyai nilai koefisien regeresi linier berganda sebesar 0,535 dan variabel komitmen organisasi mempunyai nilai koefisien regresi linier berganda besar 1,551

\section{Kesimpulan}

Kesimpulan yang dapat diambil dari penelitian ini adalah hipotesis pertama yang menyatakan bahwa partisipasi penyusunan anggaran, kepuasan kerja dan komitmen organisasi secara simultan berpengaruh signifikan terhadap kinerja organisasi pada Dinas Kebudayaan, Pariwisata, Kepemudaan dan Olahraga Kabupaten Barito Timur.

Partisipasi penyusunan anggaran dan komitmen organisasi secara parsial berpengaruh signifikan terhadap kinerja organisasi sedangkan kepuasan kerja tidak berpengaruh signifikan 
secara parsial terhadap kinerja organisasi pada Dinas Kebudayaan, Pariwisata, Kepemudaan dan Olahraga Kabupaten Barito Timur.

Partisipasi penyusunan anggaran merupakan variabel yang paling dominan berpengaruh terhadap kinerja organisasi pada Dinas Kebudayaan, Pariwisata, Kepemudaan dan Olahraga Kabupaten Barito Timur.

\section{DAFTAR PUSTAKA}

Adrianto, Yogi. 2008. Analisis Pengaruh Partisipasi Penyusunan Anggaran Terhadap Kinerja Manajerial Dengan Kepuasan Kerja, Job Relevant Information Dan Kepuasan Kerja Sebagai Variabel Moderating. (Studi Empiris Pada Rumah Sakit Swasta di Wilayah Kota Semarang). Tesis Universitas Diponegoro Semarang.

Astuti, Dwi. 2013. Pengaruh Partisipasi penyusunan anggaran terhadap kinerja manajerial dengan komitmen organisasi sebagai variabel moderating pada Perusahaan Daerah Air Minum (PDAM) Se Karesidenan Surakarta. Universitas Muhammadiyah Surakarta

Bangun, Andarias. 2009. Pengaruh Partisipasi Dalam Penyusunan Anggaran, Kejelasan Sasaran Anggaran dan Struktur Desentralisasi Terhadap Kinerja Manajerial SKPD Dengan Pengawasan Internal Sebagai Variabel Pemoderasi (Studi Kasus Pada Pemerintah Kabupaten Deli Serdang. Tesis Universitas Sumatera Utara. 2009.

Budi, HK. 2016. Pengaruh Partisipasi Penyusunan Anggaran Terhadap Kinerja Manajerial : Komitmen Organisasi Sebagai Variabel Mediasi. Jurnal Akuntansi Vol.8 No.2 November 2016 : 203-213. Fakultas Ekonomi Universitas Pelita Harapan.

Dianawati, Eris. 2009. Pengaruh Partisipasi Penyusunan Anggaran Terhadap Kinerja Manajerial: Komitmen Organisasi Dan Job Related Stress Sebagai Variabel Intervening. Jurnal Ekonomi Modernisasi, 5(1), 1-18. Retrieved from http://ejournal.unikama.ac.id/index.php/JEKO/article/view/246

Fahrianta, Riswan Yudhi. 2001. Pengaruh Tidak langsung Sistem Penganggaran Terhadap Kinerja Manajerial : Motivasi sebagai Variabel Intervening (Studi Empiris pada Perusahaan Manufaktur di Indonesia). Tesis Magister. Universitas Diponegoro. Semarang.

Ghozali, Imam. 2002. Aplikasi Analisis Multivariate Dengan program SPSS. Badan Penerbit Universitas Diponegoro.

Ghozali, Imam. 2009. Aplikasi Analisis Multivariate Dengan program SPSS. Badan Penerbit Universitas Diponegoro.

Gujarati, Damodar. 1993. Ekonometrika dasar. Cetak Ketiga. Jakarta ; Erlangga.

I Made Pradana. 2002. Pengaruh Motivasi dan Pelimpahan Wewenang sebagai Variabel Moderating Terhadap Hubungan Antara Partisipasi Penyusunan Anggaran dan Kinerja Manajerial (Studi Empiris pada Hotel Bintang Di Bali). Tesis-S2. Universitas Diponegoro. Semarang.

Ivancevich, John, M, dkk. 2008. Perilaku dan Manajemen Organisasi. Jilid 1 dan 2 Jakarta : Erlangga.

Kadek Juli Suwardana \& I Ketut Suryanawa. 2008. Pengaruh Partisipasi Penyusunan Anggaran pada Kinerja Manajerial dengan Komitmen Organisasi Sebagai Variabel Moderasi. Universitas Udayana. Jurnal Ilmiah Akuntansi dan Bisnis. Volume 5 No. 1, Januari 2010.

Mahmud. 2013. Metode Penelitian Pendidikan. Bandung : CV. Pustaka Setia.

Purwanto. 2009. Pengaruh partisipasi penyusunan anggaran terhadap kinerja pemerintah daerah dengan keadilan distributif, keadilan prosedural, dan goal commitment sebagai variabel moderating Studi pada Pemerintah Kabupaten Banjarnegara. Universitas Dian Nuswantoro. Semarang. 
Soleha Et Al. 2013. Kinerja Pemerintah Meningkat Seiring Dengan Tingginya Tingkat Partisipasi Dalam Penyusunan Anggaran.

Sopiah. 2008. Perilaku Partisipatif dalam Organisasional. Yogyakarta : Peningkatan Kinerja PT Andi. Manajerial : Studi Empiris pada Perusahaan Manufaktur

Supartini. 2015. Kepuasan Kerja, Komitmen Orgnaisasi, Motivasi, Gaya Kepemimpinan Terhadap Kinerja Manajerial Pemerintah Daerah. Journal.ummgl.ac.id/index.php/ bisnisekonomi/article/108. 